\section{'UF-172', a Pink Fancy-leaved Caladium Cultivar for Large Containers and Landscapes}

\author{
Zhanao Deng ${ }^{1}$ and Brent K. Harbaugh \\ University of Florida, IFAS, Department of Environmental Horticulture, \\ Gulf Coast Research and Education Center, 14625 C.R. 672, Wimauma, FL \\ 33598

\section{Natalia A. Peres \\ University of Florida, IFAS, Department of Plant Pathology, Gulf Coast Research and Education Center, 14625 C.R. 672, Wimauma, FL 33598}

Additional index words. Caladium $\times$ hortulanum, Caladium bicolor, Araceae, ornamental breeding, new cultivar

Caladiums (Caladium $\times$ hortulanum Birdsey, Araceae Juss.) are ornamental aroids valued for their bright colorful leaves. They are commonly used as container and landscape plants. Pink cultivars have been very popular and the most popular pink cultivars have been Carolyn Whorton, Fannie Munson, and White Queen (Bell et al., 1998; Deng et al., 2008). They ranked No.1, No.3, and No. 4 in acreage (or popularity) according to a 2003 survey of the caladium cultivars commercially grown in Florida, where more than $95 \%$ of the caladium tubers used in the world are produced (Bell et al., 1998; Deng et al., 2008). Developing new pink cultivars has been an important breeding objective for the University of Florida/Institute of Food and Agricultural Sciences caladium breeding program.

UF-172 is a fancy-leaved cultivar uniquely characterized with large attractive pink blotches and red petioles. It is intended for use in large containers and sunny landscapes. It has demonstrated high tuber yield potential and performed well in container forcing and landscape use. Its performance as a pot or landscape plant was significantly better than 'Carolyn Whorton', 'Fannie Munson', or 'White Queen'. 'UF-172' also sprouts earlier than these existing commercial cultivars. These characteristics should benefit growers producing tubers, those marketing potted or bedding plants, and consumers and landscapers using caladiums.

\section{Origin}

'UF-172' (Fig. 1) was initially selected in 2004 as GCREC-3141 out of a population of progeny from a cross made in 2003 between 'White Christmas' and 'Red Flash' (Fig. 2). 'Red Flash' was used as the male parent because of its plant vigor, performance in large

Received for publication 6 Oct. 2010. Accepted for publication 3 Nov. 2010.

${ }^{1}$ To whom reprint requests should be addressed; e-mail zdeng@ufl.edu. was taken 9 weeks after planting.
(RHS 54C to 54D), or yellow-green (RHS 144B), and of various sizes from $3 \mathrm{~mm}$ to more than $100 \mathrm{~mm}$, singly or coalesced. The undersurface has a grayed green (RHS 191A) margin, up to $10 \mathrm{~mm}$ wide. Primary veins are red (RHS 39D), and secondary veins are grayed green (RHS 194C). Along the major veins is a distinct bleeding band of red-purple (RHS 61B). Blotches are variable in color, from white (RHS 155D) to red (RHS 55C) or yellow-green (RHS 145A), and in size, from several millimeters to more than $100 \mathrm{~mm}$. Petioles are mostly erect, 4 to $7 \mathrm{~mm}$ in diameter at the apex and 8 to $15 \mathrm{~mm}$ in diameter at the base. Color is grayed red (RHS 182D) with streaks of brown (RHS 200A) near the apex, and changes to grayed purple (RHS 185D) with streaks of black (RHS 202A) near the base. Jumbo-sized tubers (6.4 to $8.9 \mathrm{~cm}$ in diameter) are multisegmented, bearing four to six dominant buds. Tuber surfaces are brown (RHS 200D) to grayed orange (RHS 165A) and the cortical area is yellow (RHS 10B).

containers and landscapes, large tubers, large plant and leaves, and tolerance to sun burns. 'White Christmas' was selected as one of the parents because of its large blotches and growth habit when grown in containers. The ancestry of these cultivars is unknown.

\section{Description}

Descriptions of color [e.g., Royal Horticultural Society (RHS) 200B] for plant parts are based on comparison with the Royal Horticultural Society Color Chart (RHS, 1986). Plants used for describing color were grown in $20.3-\mathrm{cm}$ containers in a $\approx 30 \%$ shaded greenhouse from No. 1 (3.8 to $6.4 \mathrm{~cm}$ ) intact tubers.

Leaves are peltate, sagitate-cordate, $\approx 31$ $\mathrm{cm}$ long, $\approx 19 \mathrm{~cm}$ wide with red (RHS 53B, $54 \mathrm{~A}$ to $54 \mathrm{~B}$ ) palmate-pinnate venation. The upper surface has green (RHS 137A) margins, up to $10 \mathrm{~mm}$ wide, bordering the entire leaf except for the basal leaf valley where it is red (RHS 54B). White spots (RHS 155C) may appear randomly in the marginal area. Between primary veins are numerous blotches in various colors, white (RHS 155C), red

\section{Performance}

'UF-172' was evaluated for tuber production and plant performance at the Gulf Coast Research and Education Center in Wimauma, FL, in 2006 and 2007. The soil was an EauGallie fine sand with $\approx 1 \%$ organic matter and a $\mathrm{pH}$ of 6.2. In 2006, raised ground beds (91 $\mathrm{cm}$ wide, $20 \mathrm{~cm}$ high) were fumigated on 30 Mar. with a mixture of $67 \%$ methyl bromide and $33 \%$ chloropicrin (by volume) at the rate of $196 \mathrm{~kg} \cdot \mathrm{ha}^{-1}$ and covered with white-on-black plastic mulch. Caladium seed pieces (tuber pieces, $\approx 2.54 \mathrm{~cm} \times \approx 2.54 \mathrm{~cm} \times \approx 2.54 \mathrm{~cm}$ ) were planted in the beds on 11 Apr. with $15-\mathrm{cm}$ spacing between rows and in rows. A constant water table was maintained below the beds using the seep irrigation system (Geraldson et al., 1965). Osmocote 18N-2.6P10K 8-9 month controlled release fertilizer (Scotts Co., Marysville, $\mathrm{OH}$ ) was applied to the bed surface when shoot tips were emerging from the soil with nitrogen $(\mathrm{N})$ at $336 \mathrm{~kg} \cdot \mathrm{ha}^{-1}$. In 2007, the beds (71 cm wide, $21 \mathrm{~cm}$ high) were fumigated on 3 Apr. using the same

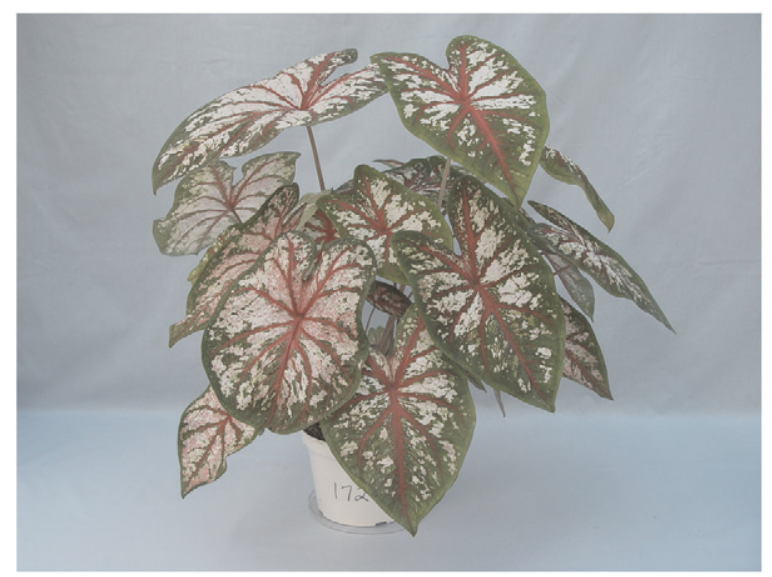

Fig. 1. Plant of 'UF-172' forced from one intact No. 1 tuber (3.6 to $6.4 \mathrm{~cm}$ in diameter) in a 12.7-cm pot. The tuber was planted 17 Apr. 2008, the plant was grown in a shaded greenhouse, and the photograph 
fumigant mixture $\left(196 \mathrm{~kg} \cdot \mathrm{ha}^{-1}\right)$. Caladium seed pieces were planted on 16 Apr. with 25.4 $\mathrm{cm}$ between-row spacing and $15.2 \mathrm{~cm}$ in-row spacing. A drip irrigation system was used to provide water $\left(\approx 6 \mathrm{~mm} \cdot \mathrm{d}^{-1}\right)$ and $6 \mathrm{~N}-0.8 \mathrm{P}-3.9 \mathrm{~K}$ soluble fertilizer with $\mathrm{N}$ at the rate of $\approx 1.9$ $\mathrm{kg} \cdot \mathrm{ha}^{-1} \cdot \mathrm{d}^{-1}$ (total $\mathrm{N}$ at $290 \mathrm{~kg} \cdot \mathrm{ha}^{-1}$ per growing season).

Field plots were organized in a randomized complete block design consisting of three replications, and each plot contained 30 propagules. Tubers were dug in Dec. 2006 and Jan. 2008, respectively. Dried tubers were weighed and counted per plot. They were then graded by maximum diameter: No. 2 (2.5 to $3.8 \mathrm{~cm})$, No. 1 (3.8 to $6.4 \mathrm{~cm})$, Jumbo $(6.4$ to $8.9 \mathrm{~cm})$, Mammoth $(8.9$ to $11.4 \mathrm{~cm})$, and Super Mammoth (greater than $11.4 \mathrm{~cm}$ ).

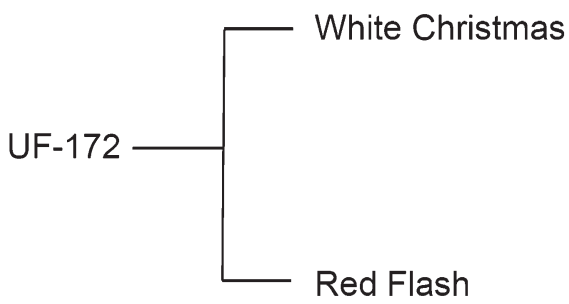

Fig. 2. Pedigree of caladium cultivar UF-172.
The production index (PI), an indicator of economic value of the harvested tubers, was calculated as: $\mathrm{N}($ No. 2$)+2 \mathrm{~N}$ (No. 1) $+4 \mathrm{~N}$ (Jumbo) $+6 \mathrm{~N}$ (Mammoth) $+8 \mathrm{~N}$ (Super Mammoth) in which $\mathrm{N}=$ number of tubers in each grade. An analysis of variance was conducted using the GLM procedure in the SAS program (SAS Institute, 2009) to compare the performance of 'UF-172' with that of three commercial cultivars, Carolyn Whorton, Fannie Munson, and White Queen. 'Carolyn Whorton' is the most popular and productive cultivar with pink blotches, somewhat similar to 'UF-172' in leaf coloration pattern. 'Fannie Munson' and 'White Queen' rank No. 3 and No. 4 , respectively, in acreage among all pink commercial cultivars (Bell et al., 1998; Deng et al., 2008).

In 2006, 'UF-172' and 'Carolyn Whorton' had similar tuber weights $(6.2 \mathrm{~kg}$ and $6.0 \mathrm{~kg})$, number of marketable tubers (56.5 and 62.1), and PI value (196 and 169) (Table 1). 'UF172 ' and 'Carolyn Whorton' tuber weights were $150 \%$ to $200 \%$ greater than the tuber weights of 'Fannie Munson' and 'White Queen'; 'UF-172' and 'Carolyn Whorton' PIs were $28 \%$ to $53 \%$ greater than the PIs of 'Fannie Munson' and 'White Queen', respectively. In 2007, 'UF-172' tuber weight was $39 \%$ greater and PI 16\% higher than corresponding values for 'Carolyn Whorton'. 'UF-
172 ' tended to produce larger tubers than 'Carolyn Whorton': more tubers in Super Mammoth (7.0\% versus $2.0 \%)$ and less in No.2 (18.0\% versus $44.7 \%)$ in 2006 , and more in Mammoth (30.0\% versus $10.0 \%)$ and less in No.2 (4.7\% versus 34.0\%) in 2007 (Table 1). These results indicate that 'UF172 ' is a very productive cultivar.

Landscape performance under full-sun conditions was evaluated in 2006 and 2007 on the same plots used for evaluating tuber production. The overall plant performance was rated on 2 Aug. and 7 Sept. in the 2006 growing season and on 26 July, 28 Aug., and 25 Sept. in the 2007 growing season on a scale of 1 to 5 with 1 being very poor (few leaves and lack of vigor) and 5 being excellent (full plants, numerous leaves, and bright color display). At the same time of plant performance evaluation, leaf sunburn tolerance was rated on a scale of 1 to 5 with 1 being very susceptible to sun burns and showing numerous sun-damaged areas or holes on leaves and 5 being resistant to sun burns and not showing any sun-damaged areas. At $\approx 4$ months after planting, plant height, number of leaves, and foliar characteristics were measured.

'UF-172' was vigorous, $\approx 50 \%$ taller than 'Carolyn Whorton', and $\approx 100 \%$ taller than 'Fannie Munson' and 'White Queen' (Table 2). 'UF-172' and 'Carolyn Whorton' produced a

Table 1. Tuber weight, production index, number, and grade distribution of five caladium cultivars (2006 and 2007). ${ }^{2}$

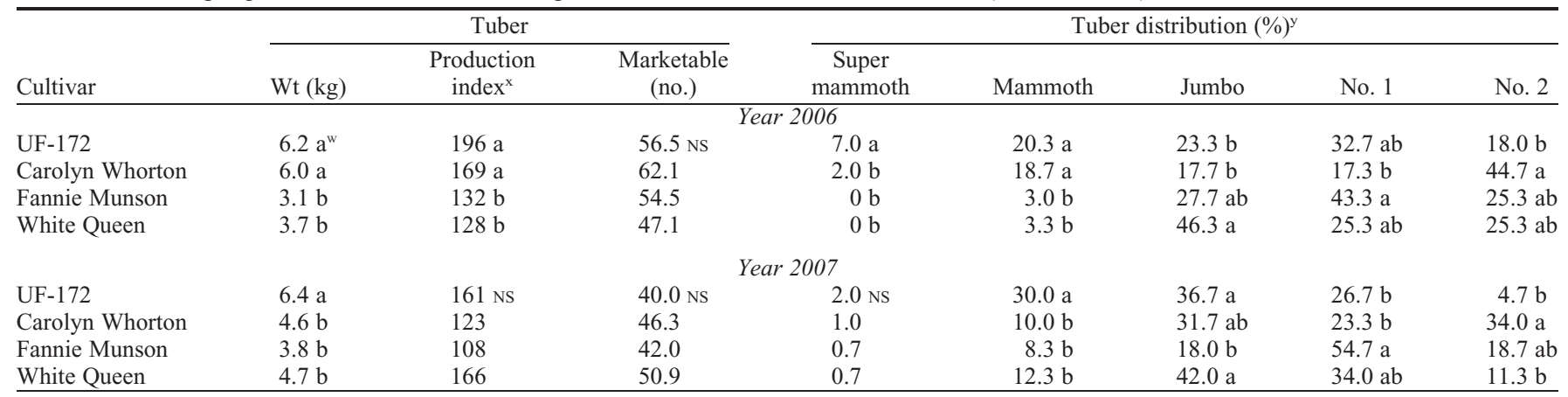

${ }^{2}$ Values presented are means of three replications with 30 propagules planted in a plot.

yTubers graded by maximum diameter: No. $2(2.5$ to $3.8 \mathrm{~cm})$, No. 1 (3.8 to $6.4 \mathrm{~cm})$, Jumbo (6.4 to $8.9 \mathrm{~cm})$, Mammoth $(8.9$ to $11.4 \mathrm{~cm})$, and Super Mammoth (greater than $11.4 \mathrm{~cm}$ ). Tuber distribution data $(\%)$ were transformed using the formula arcsine [square root (percentage/100)] before analysis of variance and mean separation.

${ }^{x}$ The production index is an indicator of economic value of the crop harvested and is calculated as: N (No. 2) $+2 \mathrm{~N}($ No. 1$)+4 \mathrm{~N}(\mathrm{Jumbo})+6 \mathrm{~N}(\mathrm{Mammoth})+8 \mathrm{~N}$ (Super Mammoth), in which $\mathrm{N}=$ number of tubers in each grade.

wMean separation within column by Fisher's least significant difference test at $P \leq 0.05$.

NS $=$ non-significantly different within column by $\mathrm{F}$ test at $P=0.05$.

Table 2. Plant characteristics, performance, and sun tolerance from planting 2.54-cm caladium tuber propagules in ground beds in full sun (2006 and 2007$){ }^{z}$

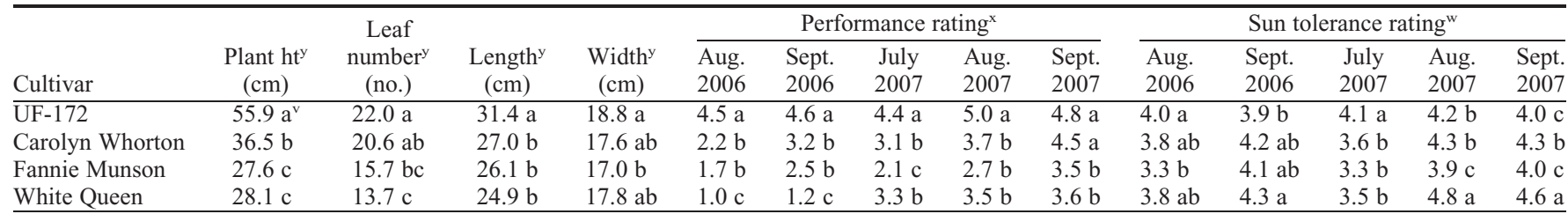

${ }^{2}$ Values presented for plant height, leaf number, length and width are means of three replications with three plants measured per plot per year, whereas performance and sunburn tolerance ratings are means of three replications based on whole plot evaluation.

${ }^{y}$ Data were taken over two growing seasons (2006 and 2007), $\approx 4$ months (Aug. 2006 and 2007) after tubers were planted in April each year.

xPlants were rated on a scale of 1 to 5 with 1 being very poor, 3 fair and acceptable, and 5 being excellent in plant vigor, fullness, and color display.

"Plants' sunburn tolerance was rated on a scale of 1 to 5 with 1 being very poor, 3 fair and acceptable, and 5 being excellent without showing any signs of leaf burns or resulted holes on leaf surfaces.

'Mean separation within columns by Fisher's least significant difference test at $P \leq 0.05$. 
Table 3. Plant performance for caladium cultivars grown from No. 1 tubers in 11.4-cm containers in a $45 \%$ shaded glasshouse, 2007 , Wimauma, FL. ${ }^{2}$

\begin{tabular}{|c|c|c|c|c|c|c|c|c|c|c|c|c|}
\hline \multirow[b]{2}{*}{ Cultivar } & \multicolumn{2}{|c|}{ Days to sprout ${ }^{y}$} & \multicolumn{2}{|c|}{ Plant ht $(\mathrm{cm})$} & \multicolumn{2}{|c|}{ Leaves (no.) } & \multicolumn{2}{|c|}{ Leaf length $(\mathrm{cm})$} & \multicolumn{2}{|c|}{ Leaf width $(\mathrm{cm})$} & \multicolumn{2}{|c|}{ Quality rating } \\
\hline & Intact & $\overline{\text { De-eye }}$ & Intact & $\overline{\text { De-eye }}$ & Intact & De-eye & Intact & De-eye & Intact & De-eye & Intact & De-eye \\
\hline UF-172 & $23.7 \mathrm{~b}$ & $24.0 \mathrm{~b}$ & $41.6 \mathrm{NS}$ & $34.3 \mathrm{NS}$ & $23.3 \mathrm{a}$ & $24.8 \mathrm{a}$ & $28.6 \mathrm{~b}$ & $24.9 \mathrm{NS}$ & $20.1 \mathrm{~b}$ & $16.5 \mathrm{NS}$ & $3.9 \mathrm{a}$ & $4.4 \mathrm{a}$ \\
\hline Carolyn Whorton & $28.4 \mathrm{a}$ & $30.0 \mathrm{a}$ & 45.4 & 33.9 & $9.4 \mathrm{~b}$ & $13.3 \mathrm{~b}$ & $32.8 \mathrm{a}$ & $24.6 \mathrm{NS}$ & $22.3 \mathrm{a}$ & $16.4 \mathrm{NS}$ & $2.7 \mathrm{~b}$ & $3.3 \mathrm{~b}$ \\
\hline
\end{tabular}

${ }^{\mathrm{z}}$ Values represent the means of 10 plants produced from intact or de-eyed No. 1 (3.8 to $6.4 \mathrm{~cm}$ in diameter) tubers planted individually per container. Data were taken 8 weeks after planting.

${ }^{\mathrm{y}}$ Number of days from planting to the first unfurled leaf. Mean separation within column by Fisher's least significant difference test at $P \leq 0.05$.

NS = non-significantly different within column by $\mathrm{F}$ test at $P=0.05$.

similar number of leaves (20 to 23), but leaves of 'UF-172' were more than $5 \mathrm{~cm}$ longer and nearly $2 \mathrm{~cm}$ wider. 'Carolyn Whorton' is considered as a sunburn-tolerant cultivar (Bates-Cantwell, 2001), and it received a rating between 3.6 to 4.2 in 2006 and a rating of 3.6 to 4.3 in 2007 (Table 2). In both 2006 and 2007, 'UF-172' received similarly high ratings (3.9 to 4.0) as 'Carolyn Whorton', and this indicated a high level of sunburn tolerance in 'UF-172'. With the ability to produce numerous leaves that are tolerant of sunburns, 'UF-172' performed very well in both growing seasons, receiving performance ratings 4.5 to 4.6 in 2006 and 4.4 to 5.0 in 2007 , which were significantly higher than the scores of 'Carolyn Whorton' (2.2 to 3.2 in 2006 and 3.1 to 3.7 in 2007), except for one evaluation in Sept. 2007 (4.8 for 'UF-172' and 4.5 for 'Carolyn Whorton').

The suitability of 'UF-172' for container forcing was evaluated by forcing tubers in 11.4-cm containers and comparing them with forced plants of 'Carolyn Whorton', which has long been valued for its pot performance. 'UF-172' could be marketed in the same leaf color/coloration pattern as "Carolyn Whorton'. No. 1 tubers were planted either intact or de-eyed in a peat/vermiculite mix (VerGro Container Mix A; Verlite, Tampa, FL) on 26 Mar. 2007. The study was conducted in a greenhouse with $45 \%$ light exclusion during the summer in Wimauma, FL. Average daily temperatures ranged from a low of $16^{\circ} \mathrm{C}$ at night to $29^{\circ} \mathrm{C}$ during the day during the experiment. Potted plants were arranged on metal benches in the greenhouse in a randomized complete block design with 10 replications. Plant height, number of leaves, and foliar characteristics were recorded 8 weeks after planting.

'UF-172' sprouted $\approx 24 \mathrm{~d}$ after planting either intact and de-eyed tubers, 5 (intact) or 6 (de-eyed) days earlier than 'Carolyn Whorton', a cultivar known in the industry as a quick-to-sprout cultivar (Table 3 ). When intact tubers were planted, 'UF-172' plants were $\approx 4 \mathrm{~cm}$ shorter than 'Carolyn Whorton' plants; when de-eyed tubers were used, 'UF172 ' plants were similar to 'Carolyn Whorton' plants in height $(\approx 34 \mathrm{~cm}$ tall). 'UF-172' plants, from intact or de-eyed tubers, each produced 23 to 25 leaves by the eighth week after planting. This was approximately twice the number of leaves 'Carolyn Whorton' plants produced. With these many leaves, 'UF-172' plants were full and received quality ratings of 3.9 to 4.4 , significantly higher than ratings for 'Carolyn Whorton' (2.7 to 3.3 ).

\section{Recommendation}

'UF-172' is intended for use in large containers and landscapes. It has demonstrated potential to yield well in tuber production and to perform well in container forcing and landscape use. Its performance as a pot or landscape plant was significantly better than 'Carolyn Whorton', currently the most popular fancy-leaved pink cultivar on the market. 'UF172 ' has the potential to produce prefinished or finished pot plants several days to 1 week earlier than 'Carolyn Whorton'. In pot caladium plant production, tuber de-eyeing will be required for production of 'UF-172' in small containers (10 to $15 \mathrm{~cm}$ diameter). In the landscape, 'UF-172' can be planted in sunny or shady locations.

Although extensive research and evaluations of these cultivars have been performed on small acreages, tuber producers are encouraged to plant only limited quantities of 'UF-172' until they have gained experience in producing these cultivars. Standard postharvest treatment of tubers is recommended (Harbaugh and Tjia, 1985) and pre-plant hot water treatment of tubers (Rhodes, 1964) is encouraged to prolong their life.

\section{Availability}

A patent will be applied for 'UF-172' by the Florida Agricultural Experiment Station and production of this cultivar is to be with a licensing agreement with the Florida Foundation Seed Producers, Inc., P.O. Box 309, Greenwood, FL 32443. Information on tuber availability and propagation agreements can be obtained from the Florida Foundation Seed Producers, Inc.

\section{Literature Cited}

Bates-Cantwell, T. 2001. The ins and outs of caladiums. GPN-Greenhouse Product News 11: 12-20.

Bell, M.L., G.J. Wilfret, and D.A. DeVoll. 1998. Survey of caladium tuber producers for acreage of cultivars grown. Proc. Fla. State Hort. Soc. 111:32-34.

Deng, Z., B.K. Harbaugh, R.K. Schoellhorn, and R.C. Andrew. 2008. 2003 Survey of the Florida caladium tuber production industry. Univ. of Fla. /IFAS extension fact sheet, ENH 1007. 16 July 2010. <http://edis.ifas.ufl.edu/EP258>.

Geraldson, C.M., A.J. Overman, and J.P. Jones. 1965. Combination of high analysis fertilizers, plastic mulch and fumigation for tomato production on old agricultural land. Proc. Soil Crop Sci. Soc. Fla. 25:18-24.

Harbaugh, B.K. and B.O. Tjia. 1985. Commercial forcing of caladiums. Univ. of Fla. IFAS Agr. Ext. Serv. Circ. 621.

Rhodes, H.L. 1964. Effect of hot water treatment of seed tubers and soil fumigation for control of root-knot on yield of caladiums. Plant Dis. Rptr. 8:568-571.

Royal Horticultural Society. 1986. RHS colour chart. Royal Hort. Soc., London, UK.

SAS Institute. 2009. The SAS system for Windows. Release 9.2. SAS Inst., Cary, NC. 